\title{
HEALTH PROMOTION NEEDS OF HAMMANSKRAAL FAMILIES WITH ADOLESCENTS ORPHANED BY HIVIAIDS
}

\section{Peu}

MA Cur (Community Nursing), PhD student

Lecturer, Department of Nursing Science, University of Pretoria

Corresponding author: mpeu@up.ac.za

\author{
Prof NC van Wyk \\ $\mathrm{PhD}$ (Community Nursing) \\ Professor and Head of Department, Department of Nursing Science, University of Pretoria
}

\section{Dr ADH Botha}

D Cur (Critical care)

Senior Lecturer, Department of Health Studies, University of South Africa

Keywords: health promotion; families; adolescents orphaned by HIVIAIDS; basic needs; rural homes

\begin{abstract}
Health promotion is regarded as the cornerstone of good health. It is the action expected from individuals and families in order to better their own health situation. Health promotion is an art and science (Edelman \& Mandle, 2002:16) that is integrated into the primary health care to reduce existing health problems. The purpose of the research on which this article is reporting, was to explore and describe the health promotion needs of families with adolescents orphaned by human immunodeficiency virus or acquired immune deficiency syndrome (HIVIAIDS). The research was located within a qualitative paradigm that is both exploratory and descriptive. Eight families who were purposely selected participated in the research process. Qualitative methods, such as group interviews and field notes were utilised to collect data. The health promotion needs of the families with adolescents orphaned by HIVIAIDS were explored and described. Tesch's analysis process, which entails a series of steps, was followed (Creswell, 2003:192). Themes, categories and subcategories that form the central focus of health promotion needs emerged during the data analysis. These themes, categories and subcategories are used to develop guidelines for health promotion.
\end{abstract}

\section{OPSOMMING}

Die bevordering van gesondheid is die hoeksteen van gesondheid. Dit is die aksie wat van individue en familie verwag word, sodat hulle hul eie gesondheidstoestand kan verbeter. Die bevordering van gesondheid is ' $n$ kuns en ' $n$ wetenskap, wat geïntegreer is in primêre gesondheidsorg, om bestaande gesondheidsprobleme te verminder (Edelman \& Mandle, 2002:16). Die doel van die navorsing, waarna in hierdie artikel verwys word, was om uit te vind wat die gesondheidsorgbehoeftes van families, met adolessente wat wees gelaat is as gevolg van menslike immunogebrek virus of verworve immuungebrek sindroom (MIVIVIGS), is, en dit te beskryf. Die navorsing was binne die raamwerk van ' $n$ kwalitatiewe paradigma, wat eksplorerend en beskrywend is. Agt families, wat vir die doel geselekteer is, het aan die navorsing deelgeneem. Kwalitatiewe metodes, soos groepsonderhoude en veldnotas, is gebruik om data in te samel. Die gesondheidsorgbehoeftes van die families, met adolessente wat wees gelaat is as gevolg van MIVIVIGS, is ondersoek en beskryf. Tesch se analiseproses, wat uit ' $n$ aantal stappe bestaan, is gevolg (Creswell, 2003:192). Temas, kategorieë en sub-kategorieë, wat die sentrale fokus van die gesondheidsorgbehoeftes vorm, het uit die data-analise na vore gekom. Hierdie temas, kategorieë en sub-kategorieë, is gebruik om riglyne te ontwikkel vir gesondheidsbevordering. 


\section{INTRODUCTION}

Health promotion is recognised as one of the most important components of public health and community health practice. This includes all the efforts that seek to move people closer to optimal well-being or higher levels of wellness (Allender \& Spradley, 2005:12). It is the action expected from individuals and families in order to better their own health situation in rural communities because of a lack of resources in these communities. Inadequate health promotion leads to the occurrence of chronic diseases such as infection as a result of the HIVIAIDS. It is, however, not sufficient for only the health-care providers to engage in health promotion activities without the involvement and participation of individuals and families. Therefore, families with adolescents orphaned by HIVIAIDS are expected to be involved in the promotion of the health of their relatives, including adolescents, and these people should be made aware of their role in this.

Health promotion is a component of primary health care that calls upon the resources, skills, time, energy and funds of communities and governments (Department of Health, 2001a:1-2). It is a service that is rendered by health-care providers within the community when chronic diseases such as cancer, AIDS and hypertension occur, in order to minimise further complications. A wide range of diseases and people is therefore involved. For this reason, the South African government invited all the stakeholders from the governmental and non-governmental organisations as well as the community to participate in the rendering of health promotion in home-based care in order to prevent health complications that may result from chronic diseases, such as HIVIAIDS (Department of Health, 2001a:1).

Estimates set out by the Department of Health (2000:67) suggest that from all the people living with HIV infection worldwide, six out of every ten men, eight out of every ten women, and nine out of every ten children reside in Sub-Saharan Africa. These figures provide sufficient evidence to make HIVIAIDS both a regional and a national priority (Department of Health, 2000:67).

A comprehensive home-based care programme, including health promotion strategies, needs to be established and rendered in areas where children are hard hit by the HIVIAIDS epidemic. An epidemic of this nature destroys families and leaves orphaned children without care and support. It is of the utmost importance to consider all children orphaned by HIVIAIDS just as unique as all other children in South Africa. As stated in the South African Constitution (Act 108 of 1996), all children, irrespective of the status of the child, deserve good nutrition, education, proper treatment, social security, leisure and recreation (Republic of South Africa 1996, Sections 27 and 28).

Despite the involvement of governmental and nongovernmental organisations in mitigating the impact of HIVIAIDS, the impact of the disease places psychological strain on the victims and their families. While the South African government is on track towards prevention and reduction of the impact of the disease, the families on the other hand continue to face the socioeconomic burdens of health care and funeral costs when breadwinners become ill and die.

The purpose of the research on which this article was based, was therefore to explore and describe the healthpromotion needs of families in the community with adolescents orphaned by HIVIAIDS. A qualitative paradigm was followed where the health-promotion needs of families with adolescents orphaned by HIVI AIDS were explored and described. A brief overview of the background, followed by objectives, conceptualisation, methods, discussions and conclusions is demonstrated.

\section{BACKGROUND OF THE PROBLEM}

The surveys conducted on women attending antenatal clinics provide good estimates of HIV prevalence and trends for the past ten years (Department of Health, 2000:6-7). The incidence of HIV in women attending antenatal clinics has increased by $15.3 \%$ (Department of Health, 2000:6-7). The statistics also reveal that one in every pregnant woman attending the clinic,was HIVI AIDS positive (UNAIDS, 2006:17). Even though these women were infected, there was also a gradual escalation of HIV (UNAIDS, 2006:17). Furthermore, the rural areas in the Kwa Zulu Natal, Mpumalanga, Free State and Limpopo provinces are most affected. In comparison with the other provinces in South Africa, KwaZuluNatal has the highest HIV prevalence among pregnant women 37.5\%, followed by Mpumalanga 32.6\%, Free 
State 30.1\%, North West 29.9\% and Gauteng 29.6\% (Abdool-Karim \& Abdool-Karim, 2005: 56). The provinces with the lowest statistics of HIV and AIDS are Western Cape 13.1\%, followed by Northern Cape 16.7\% and Limpopo Province 17.5\% (Abdool-Karim \& AbdoolKarim, 2005:56). Mother-to-child transmission (MTCT) of HIV infection can be prevented by appropriate treatment. However, while their infants survive, the mothers do not, and children are left in the care of other family members, often the elderly.

The Department of Health (2000:10) recommends that interdepartmental and intersectorial response to the epidemic should be encouraged. The provision of care to children who have lost their parents through HIVI AIDS is a priority for the national government. In addition to the mobilisation of financial and material resources, health-care services have to be developed to meet these children's unique needs.

In response to the increase of the HIVIAIDS epidemic and the limited health-care resources in South Africa, the government took the initiative to shift the care of these patients from hospital settings to community and home-based care settings. Patients and their families are empowered to control their own health situation. The promotion of health of the families and thus also that of the orphaned children is therefore indicated. The care should be holistic, person-centred and sensitive to the patient's culture, religion and value system concerning respect, privacy and dignity (Department of Health, 2001a:4-5). Health promotion in rural communities should be seen as an empowerment strategy that will allow capacity building and that will promote the autonomy and functional independence of the individual and family (Department of Health, 2001a:4).

Families who take care of HIVIAIDS-orphaned adolescents are faced with challenges concerning health promotion as the latter forms part of home-based health care. Guidelines and strategies need to be formulated to assist families to engage in health promotion of families with special emphasis on that of orphaned adolescents.

\section{PROBLEM STATEMENT}

The lack of health-related resources, such as the lack of health-care services, lack of information on health care and poor access to health-care services in South Africa makes home-based health promotion inevitable. Health promotion in home-based care is a priority in the sense that there is a shortage of hospital beds as a result of chronic diseases such as AIDS, the escalating cost of institutional care, and the lack of resources for treatment (Department of Health, 2001a:2). The implementation of health promotion strategies in rural communities will therefore enable families with adolescents who have lost their parents as a result of HIV/ AIDS to give relevant care to their own members.

As yet there is no formal, written health promotion guidelines for families with adolescents who where recently orphaned by HIVIAIDS in rural Hammanskraal. The question below is therefore applicable: What are the health promotion needs for Hammanskraal families with adolescents orphaned by HIVIAIDS?

The focus is on adolescents as they will be the parents of the next generation and will therefore have to be role models in health promotion.

\section{THE OBJECTIVE OF THE RESEARCH}

The following specific objective forms the basis for the research, namely:

- To describe the health promotion needs of families in rural Hammanskraal with adolescents orphaned by HIVIAIDS.

\section{DEFINITIONS OF CONCEPTS}

\section{Health promotion:}

O'Donnell ((1987) in Edelman \& Mandle, 2002:16) defines health promotion as the science and art of helping people to change their lifestyle in order to move towards a state of optimal health.

\section{Adolescent orphaned by HIVIAIDS:}

For the purpose of the study on which this article is based, a recently orphaned adolescent refers to any adolescent who has lost his/her last surviving parent and who is between the ages 10 and 17 years old. The HIVIAIDS status of these orphans is not known and is not part of the current research focus. 


\section{RESEARCH METHOD}

The researcher worked within a qualitative paradigm. An exploratory, descriptive and contextual method was utilised to explore the needs related to the health promotion of adolescents orphaned by HIVIAIDS.

\section{RESEARCH POPULATION AND SAMPLING}

The research population had to meet certain inclusion criteria. Families with adolescents orphaned by HIVI AIDS who are residing in rural Hammanskraal villages were involved in the research interviews. The participants who were involved in this research were grandmothers, a grandfather, related adults such as siblings, as well as orphaned adolescents aged between 10 and 17 years old. The families who were chosen to participate in the research were poor and could not survive on their own. The researcher included only adolescent orphans between the ages of 10 and 17 years, who had lost their last surviving parent not long before the research was conducted. Families with older adolescents were not involved as well as families with surviving parent. Because of ethical reasons that involve confidentiality, a social worker of the Moretele Sunrise Hospice was involved in order to select families that meet the criteria set for the research and these families form part of the research population. All the families with adolescents between ten and seventeen years old who have been orphaned by HIVIAIDS and who were living in Hammanskraal and who were in a way associated with the hospice were included in the study population.

Purposive sampling was used to sample the population for participation. For the purposes of this study, the researcher requested a knowledgeable social worker to handpick study participants. This method was used to select families to be included in the study and all participants were included irrespective of their HIV status. This type of sampling is based on the belief that a researcher's knowledge about the population can be used to handpick cases to be included in the sample (Polit, Beck \& Hungler, 2001:234; Burns \& Grove, 2003:43).

\section{DATA COLLECTION}

Data were collected by means of group interviews until saturation was achieved. Group interviews were conducted with families with adolescents orphaned by HIVI AIDS. Eight groups of families participated in the discussions. A tape recorder was used to record all the discussions of the groups. The participants were arranged in smaller family groups and they provided the researcher with data of a qualitative nature.

The interviews were conducted in the homes of the participants in 2005. Interviews were conducted for 45 minutes to an hour. Follow-up interviews were conducted until data were saturated. Three to four interviews with each group were conducted. The researcher also created a favourable and non-threatening environment for the interviews by warmly thanking the participants for their willingness to participate in the research (Rossouw, 2003:146-147). The participants were interviewed in Tswana, as it was their preferred home language. The transcripts were then later translated and typed into English. Each family group was interviewed separately.

A tape recorder was used during the interviews in order to capture all the data available. Various communication skills, such as paraphrasing, probing and reflecting, were employed during the interviews.

Paraphrasing was used frequently during the interviews in order to ensure that the research question was understood. The research question: "What do you need in order to promote your own health" was posed clearly and the participants were expected to restate the ideas contained in the question clearly and concisely (Burns \& Grove, 2003:491).

Probing was also used to draw more information from the participants during the interviews. This involved repetition of the original question and long pauses, which were intended to communicate with the participants (Babbie \& Mouton, 2007:253). The question "What do you need in order to promote your own health?" was frequently asked. During the research process, various methods, such as asking "Anything else?", were also used to get as much information from the participants as possible. These neutral probing methods were used in order to avoid affecting the nature of the responses (Babbie \& Mouton, 2007:253-254).

Reflection was used in order to remind the participants of what had been previously said and in order to link 
this with current discussions. During subsequent visits, the researcher encouraged the participants to reflect on their health promotion needs (Burns \& Grove, 2003:495).

Interviews were conducted until data were saturated. After data were collected, it was transcribed and analysed. A comprehensive report on the findings of the research was written. After the initial interviews, appointments with the participants were made for two months' time in order to ensure member checking and the validity of data. The reason for the appointment was explained to the participants. Constant checks with participants have been conducted to verify the data. The researcher visited individual families, and explained and clarified the results. The participants confirmed that no incorrect data had been collected or added. The conclusions formulated from the data were discussed to ensure the validity of the findings.

Field notes were made in the forms of personal notes during the interviews with the families. These notes included both empirical observations and interpretations, and contained an objective description of events, times, places, activities and non-verbal cues. Persistent observations regarding health promotion activities during interview visits were conducted. During the research interviews, the participants were consistently observed in their homes regarding their health promotion activities. The researcher conducted several visits to collect data from the participants. The field notes were also compiled during interactions and discussions with the families.

\section{ETHICAL CONSIDERATIONS}

Permission to conduct the research in the North West Province was granted by the Jubilee District Deputy Director (Mr D Baloyi). The Ethics Committee of Faculty of Health Care Sciences of the University of Pretoria further evaluated and approved the proposal. Principles of research ethics were always applied. The following principles served as a guide in this study: beneficence, respect for human dignity, justice, informed consent, respect for vulnerable subjects and protection of human rights.

All participants were respected and treated with dignity. They were given the opportunity to make informed voluntary decisions. Freedom of decision-making was granted to all participants. The participants were treated fairly and their privacy always maintained. The participants were also guaranteed confidentiality of the information they provided. The researcher tried by all means to avoid any harm to the participants. The participants were assured that the information would not be used against them in any way (Polit, Beck \& Hungler, 2001:73-89).

The researcher made use of the second information leaflet to assist the representatives of the families who were interested in becoming research participants in making informed decisions. The visit took place one week prior to commencement of the research process. The prospective participants were fully informed of the purpose of the study, the type of data to be collected and the procedure to be followed, as well as their rights regarding participation, the nature of the commitment, potential risks and potential benefits.

The guarantee of confidentiality, voluntary consent, the right to withdraw and contact information were discussed before the data collection commenced (Polit et al. 2001:73-89). The concept of health promotion was analysed and described to enable the participants to understand it. The dissemination of the results of the research was thoroughly explained. The family representatives signed the consent form on behalf of their families before data were collected. The family members selected the representatives.

During the research process, the researcher adhered to all ethical principles applicable to the research. Standards for ethical and sound research were adhered to. The rights of the children who participated in the research were respected. Sensitive questions, such as the cause of their parents' death, were avoided (Polit et al. 2001:83).

\section{DATA ANALYSIS}

Qualitative methods of data analysis were used. Data analysis began when the first data were collected, which in turn guided decisions towards further data collection (Burns \& Grove, 2001:66). It is an ongoing process, which involves continual reflection about the data, analytical questioning and the writing of notes throughout the study (Creswell, 2003:190). 
Two independent coders who were experienced qualitative researchers and who have been involved in various research report evaluations were purposely selected and coded the transcribed and translated data. The role of the researcher was to ensure that the codes were formulated within the context of the data collected. Two coders as researchers were chosen to take part in the analysis and coding as they had not been involved in the data collection and were therefore less biased. The researcher and one co-coder could speak, read and write Tswana and English. The analysis of the data was done in English. Coders checked each other on the themes classification in the data analyses discussion. A consensus discussion was held with co-coders. The three sets of coded data were compared, discussed and adjustments were made.

Tesch's analysis process, which entails a series of steps, was followed (Creswell, 2003:192). The first interview with the first family was chosen and analysed. The coders got a sense of the transcripts by reading them repeatedly. All ideas were highlighted. Thoughts and ideas about the content of the interview were written down. Each coder completed their analysis of the transcribed interviews before comparing it with that of the others. Themes, categories and subcategories were identified through the clustering of descriptive phrases derived from the data. After a comparison, a final decision on the description of each theme was made. The data of each theme were assembled. Data were recoded when necessary to ensure credibility (Creswell, 2003:192). The description of themes and categories were presented in tables as adjuncts to the discussions. Interpretation of the meaning of data was conducted. '

\section{TRUSTWORTHINESS OF THE FINDINGS GENERATED}

Trustworthiness refers to how a researcher can convince her/his audience that the findings are correct and worth paying attention to and taking account of (Lincoln \& Guba, 1985:290). Guba's model for trustworthiness was utilised to ensure validity and reliability within the research on which this article is reporting. In this research, to establish the trustworthiness, the following strategies were used: confirmability, credibility, transferability and dependability (See Table 1).

\section{DISCUSSIONS OF THE RESULTS}

Thirteen themes, twenty-six categories and forty-five subcategories emerged from the data analysis. The themes and categories reflecting the participants' expressions are displayed in Table 2.

\section{PHYSICAL NEEDS}

The first theme that emerged relates to physical needs. Two categories, namely basic needs and unmet basic needs, emerged from the discussions. Physical needs play a major role in the survival of the individual person. These needs are also regarded as basic needs for all people irrespective of age, status or cultural background. The focus of the discussion on basic needs in this category was on food and nutrition, water and sanitation, housing, sleep and rest, elimination of body waste, stimulation and activity and the participants expressed their needs in this regard as follows: "We are suffering with hunger. We need food to feed ourselves and be alive. We need water for daily activities in the home. We need a house that belongs to us. We need our own yard. We need blankets and mattresses; the mattresses we use are too old and the springs are pointing out. Usually we use traditional exercises and games but they are not enough. I want to train to be fit".

Literature suggests that basic needs as mentioned in Table 2 need to be provided by governmental and nongovernmental organisations (Ramsden, 2002:14 \& Department of Health, 2001b:10). Emphasis was on nutrition and water as major basic needs. Allender and Spradley (2005:635) mention that adequate nutrition, as one of basic needs, should begin at birth and extend to young children and women. De Haan, Dennill and Vasuthevan (2005:210) add that correct and quality food is essential for health and life itself. It was also emphasised in the United Nations Convention on the rights of the child that all children have a right to have basic needs such as provision of food fulfilled (Ramsden, 2002). President Thabo Mbeki, in his address to the public, supported and emphasised the need for clean running water to reduce local health problems (South African Government Information, 2003:1-5). 
Table 1: Strategies to ensure trustworthiness

\begin{tabular}{|c|c|c|}
\hline STRATEGY & CRITERIA & TECHNIQUE \\
\hline Confirmability & Confirmability audit & $\begin{array}{l}\text {-The objectivity of the researcher ensured } \\
\text { confirmability. } \\
\text {-The researcher has various years of } \\
\text { experience in the community environment. } \\
\text {-The use of raw data. }\end{array}$ \\
\hline Credibility & $\begin{array}{l}\text { Triangulation } \\
\text { Member checking }\end{array}$ & $\begin{array}{l}\text {-The researcher spent 3-6 months with } \\
\text { participants. } \\
\text {-Field notes were kept. } \\
\text {-The use of different families in collecting data. } \\
\text {-Information was gathered by making use of } \\
\text { interviews, field notes, observations and } \\
\text { literature reviews to ensure triangulation. } \\
\text {-The use of three co-coders in analysing the } \\
\text { data. } \\
\text {-Constant check with participants to verify } \\
\text { findings. } \\
\text {-Coders check each other on the themes } \\
\text { classification. } \\
\text {-Persistent observations regarding health } \\
\text { promotion activities. } \\
\text {-Several visits to collect data from participants } \\
\text {-Independent co-coders were used to code and } \\
\text { verify. }\end{array}$ \\
\hline Transferability & $\begin{array}{l}\text { Dense description } \\
\text { Selected sample }\end{array}$ & $\begin{array}{l}\text {-Various interview visits were conducted. } \\
\text {-The use of purposive sampling. }\end{array}$ \\
\hline Dependability & Code-recode procedure & $\begin{array}{l}\text {-Consensus was held with co-coders. } \\
\text {-Field notes were taken and non-verbal cues } \\
\text { were noted. }\end{array}$ \\
\hline
\end{tabular}

Adapted from Lincoln and Guba (1985:290), Lehana and Van Rhyn (2003:30-31), Richter and Peu (2004)

Unmet basic needs are the second category that emerged during the data analysis. These needs are the challenges that are experienced by families in rural Hammanskraal with adolescents orphaned by HIVI AIDS. These challenges are encountered when an individual family experiences a lack of resources for basic needs. Solutions might be available but not accessible to the people at ground level. The participants in the study emphasised a lack of resources or facilities and this serves as a barrier to survival. The participants revealed that: "We have inability to pay for what is needed".
Siaens, Subbarao and Wodon (2003:2) mention that there is evidence to suggest that, on average, orphans in Africa live in poorer households compared with nonorphans. According to African tradition, the majority of these orphans are placed either in extended families or in fostering households (Siaens et al. 2003:2). It is not surprising to see poor living conditions amongst families with orphans. It can be suggested that families with a number of children without support experience poverty. 
Table 2: Themes,categories and sub-categories identified

\begin{tabular}{|c|c|c|c|}
\hline NO. & THEMES & CATEGORIES & SUBCATEGORIES \\
\hline 1. & Physical needs & $\begin{array}{l}\text { Basic needs } \\
\text { Unmet basic needs }\end{array}$ & $\begin{array}{l}\text { Food and nutrition } \\
\text { Water, sanitation and } \\
\text { elimination } \\
\text { Housing } \\
\text { Sleep and rest } \\
\text { Stimulation and activity } \\
\text { Lack of resources }\end{array}$ \\
\hline 2. & Safety/security needs & $\begin{array}{l}\text { Physical and personal } \\
\text { security } \\
\text { Financial security }\end{array}$ & $\begin{array}{l}\text { Fence surrounding house } \\
\text { Own stand } \\
\text { Employment with sufficient } \\
\text { income } \\
\text { Clothes } \\
\text { Money for healthcare and } \\
\text { clothing purposes } \\
\text { Money for educational } \\
\text { purposes }\end{array}$ \\
\hline 3. & Love and belonging needs & $\begin{array}{l}\text { Internal environment } \\
\text { External environment }\end{array}$ & $\begin{array}{l}\text { To be loved by family } \\
\text { members } \\
\text { To be loved by non-family } \\
\text { members }\end{array}$ \\
\hline 4. & Emotional needs & $\begin{array}{l}\text { Conflict } \\
\text { Recreational facilities } \\
\text { Concerns }\end{array}$ & $\begin{array}{l}\text { Fights } \\
\text { House chores } \\
\text { Disrespect toward } \\
\text { grandmothers } \\
\text { Boredom } \\
\text { Teen pregnancies } \\
\text { Worry about not be given a } \\
\text { decent funeral } \\
\text { Stigma attached to being } \\
\text { an orphan }\end{array}$ \\
\hline 5. & Family structure & $\begin{array}{l}\text { Internal family structure } \\
\text { External family structure }\end{array}$ & $\begin{array}{l}\text { Need for parental care } \\
\text { Need an elderly person }\end{array}$ \\
\hline 6. & Healthcare needs & $\begin{array}{l}\text { Clinics } \\
\text { Personnel } \\
\text { General health problems } \\
\text { and intervention needs } \\
\text { Illnesses }\end{array}$ & $\begin{array}{l}\text { Utilisation of clinics } \\
\text { Doctors and nurses } \\
\text { Treatment } \\
\text { Counselling } \\
\text { Better hygiene } \\
\text { Epilepsy } \\
\text { Arthritis } \\
\text { Epistaxis } \\
\text { Asthma }\end{array}$ \\
\hline
\end{tabular}




\begin{tabular}{|c|l|l|l|}
\hline 7. & Esteem needs & Self and others & $\begin{array}{l}\text { Need for respect, } \\
\text { recognition and dignity }\end{array}$ \\
\hline 8. & Educational needs & $\begin{array}{l}\text { Facilities } \\
\text { Constraints }\end{array}$ & $\begin{array}{l}\text { Need for school materials } \\
\text { Long distance to school } \\
\text { Lack of libraries and } \\
\text { facilities for career } \\
\text { guidance }\end{array}$ \\
\hline 9. & Spiritual needs & $\begin{array}{l}\text { Church services and other } \\
\text { related needs }\end{array}$ & $\begin{array}{l}\text { Prayer, attending church } \\
\text { ceremonies and religion }\end{array}$ \\
\hline 10. & $\begin{array}{l}\text { The need to be a whole } \\
\text { person }\end{array}$ & $\begin{array}{l}\text { Fit into the family and } \\
\text { society }\end{array}$ & $\begin{array}{l}\text { Emotions because of } \\
\text { limited choices }\end{array}$ \\
\hline 11. & Support needs & $\begin{array}{l}\text { Internal support } \\
\text { External support }\end{array}$ & $\begin{array}{l}\text { Family members } \\
\text { Community } \\
\text { Government }\end{array}$ \\
\hline 12. & Social needs & $\begin{array}{l}\text { Social needs related to } \\
\text { interaction with others } \\
\text { Social needs that } \\
\text { professionals can help with }\end{array}$ & $\begin{array}{l}\text { Recreational activities } \\
\text { Telecommunication } \\
\text { Other appliances }\end{array}$ \\
\hline 13. & $\begin{array}{l}\text { Needs related } \\
\text { technology }\end{array}$ & to & $\begin{array}{l}\text { Computers,telephones } \\
\text { Microwave and kettle }\end{array}$ \\
\hline
\end{tabular}

\section{SAFETYISECURITY NEEDS}

Participants regarded safety or security needs as an important aspect of human survival. The participants are of the opinion that a healthy family has a need to reside in a physically secure environment and families should be financially stable. The participants expressed that: "There is no security and the place is not safe, because there is no fence. One member is working and the pay is insufficient".

It was indicated that in South Africa, every 23 seconds a child is molested and every passing minute of the day a child as young as five months is gang raped (Crime Buster, 2004:1). It shows that children in this country are vulnerable and are at high risk to abuse. It is even more so in the case of this research due to their status as orphans.

South Africa is a country with a high unemployment rate. In the year 2001, the unemployment rate was 29.5\% (Van Rensburg, 2004:206). In rural areas, the unemployment rate was $30.2 \%$ (Van Rensburg, 2004:206). Kingdom and Knight (2005:1) mention that in South Africa, unemployment is extremely high and rising. Kingdom and Knight (2005:2) further indicate about $40 \%$ of adults in South Africa are unemployed.

Although money is an important need for these families, money needs to be used well and saved properly when it is available to the people. In support of how the participants have expressed themselves, the government today advocates a better life for all through a variety of strategies (Mbeki, 2004).

\section{LOVE AND BELONGING NEEDS}

Love and belonging needs emerged during data analysis. Internal and external environments emerged from love and belonging. The participants mentioned that love is needed in order to belong to a particular unit. The families with adolescents orphaned by HIVIAIDS emphasised the need to be loved, to belong to a family kinship, and also to be acceptable to, and accepted by the society. The participants indicated that they need to be loved by their family members. Family members such as uncles, aunts and grannies play an important role in love and belonging. Loving and love stimulate self-worth and self-actualisation as principles of a healthy person. The participants mentioned that: "We 
also need good attention from our schoolmates and attention from other people and our parents".

Graca Machel in the year 2003 confirmed that orphaned children cannot wait and their rights cannot be postponed (Kalideen, 2003:1). Graca further indicated that it is the responsibility of individuals, families and groups to start acting in a caring and responsible manner (Kalideen, 2003:1).

Similar ideas and opinions were expressed in Murray and Zentner (2001:160). It was stated that a family is constituted to provide an opportunity for the expression of love and support in a stable relationship benefiting all its members. The orphans also need to be loved by family members to promote their self-worth or selfesteem. If these needs are not taken into account individuals become unfriendly, and they feel unloved, rejected, abandoned and even restless (Marker, 2003:1).

\section{EMOTIONAL NEEDS}

Emotional needs as a theme emerged and was further categorised into conflict, recreational facilities and concerns. Conflict in the form of fights as a result of house chores and no respect for grandmothers are major concerns among these orphans. Participants mentioned that: "We need an elderly person who can advise us or even to stop us when we are fighting. These children are fighting and we are unable to handle the situation. We fight frequently. I always think too much, I remember my mother. I think where she has rested. We need funeral society with funeral plans, if one member dies, we must be able to bury her/him".

Death of loved ones is described by Mengel (2003:31) as emotional numbness, inner sorrow and longing, which result in a refusal to accept the changes that are associated with death. It also influences the way in which people react to death. During the current research the death of parents made the adolescents very aware of how necessary it is to prepare for death, funerals and the associated costs.

\section{FAMILY STRUCTURE NEEDS}

A family is a unit with different sub-units. The internal and external family structures emerged from family structure. Each sub-unit contributes towards the sur- vival of the whole family. Interference of one of the subunits will affect the functions of other sub-units. Family structure was mentioned as an important aspect for the survival of the family when the theme family structure emerged during data analysis. The participants mentioned that: "A complete family is necessary. There is a need for parental care".

Andrews and Boyle (2003:170) also mention that elderly individuals can provide multiple care-giving roles, such as caring for orphans. It should be noted that from an African perspective elderly community members are preferred to take care of orphans because they have the ability to transfer traditional norms to the adolescent and thus ensuring that the cultural traditions and norms are passed on to the next generation.

\section{HEALTH-CARE NEEDS}

Health-care needs specifically emerged during data analysis. It was further categorised into sub-categories namely: clinics, personnel, interventions and illnesses. Health care as a need was emphasised in the research. The participants mentioned that: "We need health care such as clinics. All clinics should be accessible for the care needed in promoting the health of these families. We need a doctor or medical aid because one of our family members is sick". "We need doctor or medical aid because one of our family member is sick". "We need good health to live longer". "She (an epileptic) is receiving treatment from the clinic".

In the strategy for the implementation of primary health care, Dennil, King and Swanepoel (2002:6) emphasise that health services such as clinics should be accessible, affordable, available, effective and efficient, and it should be supplied equally to all in the community. Geographically the community should have a clinic within five-ten $\mathrm{km}$ and there should be transport available. Dennil et al. (2002:6) further emphasise that special attention should be given to disadvantaged regions of the country, especially rural areas.

Murray and Zentner (2001:560) add that adolescents experience difficulty when dealing emotionally with chronic disease or illness because they feel different from and set apart from peers. They tend to isolate themselves from peer activities and become isolated and lonely. 
According to the Batho Pele principles, the members of the community should be consulted, and treated with courtesy. Health-care personnel, including nurses and doctors, should render a client friendly service to all people of South Africa, and high standards of services are guaranteed by the Minister of Health (Department of Public Service and Administration 1997). Good treatment could be ensured through appropriate primary health care, the implementation of the Batho Pele principles, the use of guidelines for good clinical practice, implementation of applicable legislation and adhering to treatment protocols for illnesses such as epilepsy, arthritis, epistaxis and asthma (Department of Public Service and Administration 1997).

\section{ESTEEM NEEDS}

The need for esteem and self-worth was identified. When it was explored, it became clear that the participants experienced problems regarding self-worth and esteem. The participants focused on their needs regarding respect, recognition and dignity. The majority of teenage adolescents commented that: "I want to be something when I grow old. I think if we can find a kind person, we can share our problems. The one who is approachable and sharp".

It was indicated that an adolescent needs respect and privacy (Month of the Young Adolescent, 2005:1). Carpenito-Moyet (2003:3-4) mentions that adolescents need support for the development of self-respect, recognition, honour, glory, status, independence, freedom, appreciation and dignity because these are necessary in the healthy life of an adolescent.

\section{EDUCATIONAL NEEDS}

Education as a need emerged during data analysis. The participants in this research mentioned education as a need that has an effect on the promotion of health. Education was also regarded as a right to all participants. The participants regarded education as a pathway to better their lives. The participants further added and emphasised that even though there are constraints in education, education still remains a right to all individuals irrespective of life situations. The participants expressed that: "We have no textbooks, we need school uniform, clothes as well as raincoat and umbrellas for rainy days. I travel a long distance".
The current school system in South Africa aims to produce learners who participate in their learning activities to become more responsible for their studies. They should be creative in their learning environment but the government should provide them with learning resources. Section 29 of the South African Constitution stipulates that no one should be subjected to discriminatory actions and that South African institutions such as schools have to be registered institutions in order to assist in promoting the health of the people (South Africa, 1996).

\section{SPIRITUAL NEEDS}

Spiritual needs also emerged during data analysis. The focus of discussion was on the church service-related needs and other spiritual needs. Health promotion and spirituality are concepts that are related and interlinked. When one is spiritually satisfied, that person's health is promoted. People's spiritual need is fulfilled through praying together, attending churches, the nurturing role of family members, the use of values and residing in a safe environment. The participants indicated that: "We also want to attend the church. The church enables people to pray for each other and love each other".

In view of the above comments, Spector (2004:104) suggests that religion plays a vital role in one's perception of health and illness. He further mentioned that culture and ethnicity are strong determinants in an individual interpretation of the environment and the events within the environment. The families who participated in this research have their own cultures and belong to various ethnic groups that assist them to survive. In addition, Spector (2004:116) indicates that when someone is experiencing an illness of the spirit, spiritual healing applies. Andrews and Boyle (2003:436) add that few studies conducted on African-Americans have found that they use religious beliefs to help them to cope with stress during provision of care.

\section{THE NEED TO BE A WHOLE PERSON}

The need to be a whole person emerged as a category during data analysis. The participants expressed their need to be fitted into their families and society. Due to a lack of health promotion needs, the participants emphasised that it is really difficult to align oneself with other people. The participants had the idea that the 
only way to fit into the family is to have belongings, such as a house and furniture. The participants expressed emotions and volition as: "We want a brick house. We need chairs to give visitors. We need clothing to be like other children".

Exponents of humanistic theory emphasise that an individual as a whole person, particularly in learning environment, should be considered and respected (Quinn, 2000:44), the participants wanted to be whole persons. According to humanistic learning theorists people learn better in an encouraging environment (Allender \& Spradley, 2005:289). Therefore in Maslow's Hierarchy of Human Need theory, it is asserted that meeting selfesteem needs contribute towards a feeling of self-worth thus leading to self-actualisation (Allender \& Spradley, 2005:289). Individuals are becoming beings and will never attain a state of wholeness. It is difficult to replace a lost parent, but it is however negotiable to provide a substitute parent to provide in the needs of the orphans regarding the promotion of health so that these children can be well fitted in the family and society.

\section{SUPPORT NEEDS}

The participants mentioned the need for support in health promotion. The focus was on the need for support and focused on the family, the community and the government. The participants mentioned that: "We need a person to encourage us because we are fighting. At least if the government can help to reduce the load from me. It should provide us with food and school materials".

In support of the above statements, Ramsden (2002:23) suggests that families who care for other people's children should be financially supported. He further expresses that families with orphans need financial support, such as state grants. Many of these children will be taken care of by a grandmother or other elderly relative, who may need extra help to match the responsibility. The support as it is emphasised, is needed to promote the health of the orphans.

Ramsden (2002:24) emphasises that any person, such as a neighbour or a teacher, can act as a foster parent through a children's court. The case will however be reviewed every two weeks to check whether the child is cared for. Various researchers are striving towards investigating the support that is relevant to specific communities. Amongst those researchers, Richter and Peu (2004:38-39) assisted in the investigation of the supportive needs of informal caregivers who are serving families of this nature. Richter and Peu (2004) mentioned that government should help with finance, water, security and medicines. These comments suggest that there is a need for government to support disadvantaged families.

\section{SOCIAL NEEDS}

The focus of discussion was on the social needs related to interaction with others as well as the social needs that the professionals can help with to promote the health of the families. These social needs are relevant to both orphans and substitute parents. These social-related needs would assist the orphans in thinking critically and at the same time these social-related needs will contribute to the recreational opportunity of the mentioned party. The participants expressed that: "We want basic needs such as recreation centres. We need music system because it is too quiet at home".

Elfituri, Elmahaishi and MacDonald (1999:2) indicate that the radio as a medium could influence the behaviour of people positively. They further emphasise that there is a need to use different educational and recreational media in future planning. In support of the value of recreation, Ramsden (2002:14) indicates that children have the right to play, to recreation and to participate in cultural activities. The involvement of adolescents in traditional games, however, if encouraged regularly, will promote the health of these families and their ability to cope with stressors.

\section{NEEDS RELATED TO TECHNOLOGY}

The needs related to technology were the $13^{\text {th }}$ theme that emerged during data analysis. It focused on telecommunication and other appliances. Telecommunication can be used as a medium for providing health education as it is used to contact people when necessary. The participants expressed the need for telecommunication in promoting their health. The participants explored and described telecommunication as: "We need telephone in the house in order to communicate with social worker to help us. We need telephone container where the community can come and use mobile 
telephones because I want to run a telephone business."

Telecommunication refers to communication over a distance by cable, telephone, or broadcasting (Pearsall, 2002:1472). According to the research on which this article is based, telecommunication can be used by families to exchange or share information with their external environment, such as family members. Kessler (2002:6) mentions similar information in learning communication skills, as the adolescents can express themselves more effectively, fully and authentically. The participants in the research mentioned communication as a system that carries messages on health promotion.

Communication refers to the process of exchanging feelings, desires, needs, information and opinions (McCubbin \& Dahl, 1985, in Friedman, Bowden \& Jones, 2003:267). In conclusion, families with adolescents orphaned by HIVIAIDS need to be provided with some form of communication, for an emergency or any other important incident. Their intense feelings regarding the past need to be shared in a communication process. The research, on which this article is reporting, could also assist policy-makers to integrate a need for communication in promoting the health of rural families.

\section{CONCLUSION}

The research question, What are the health promotion needs of families in rural Hammanskraal with adolescents orphaned by HIVIAIDS? guided the researcher to focus on the content of the research on which this article is reporting. Based on the above question, the researcher and participants followed the process of research. The participants were therefore expected to explore and describe their health promotion needs, which focused on the following: physical needs, safety or security needs, love and belonging needs, emotional needs, family structure needs, health-care needs; esteem needs; education needs; spiritual needs, needs to be a whole person; support needs; social needs as well as the needs related to technology. It can therefore be concluded that the majority of participants emphasised the importance of promoting their health with the help of available resources.
A small sample, including eight rural families, was used in this research. The results cannot be generalised because families are dynamic and can be influenced by their environmental settings. An urban family might, for instance, have different challenging needs as compared to a rural family.

Despite the limitations of this research, it is recommended that the identified needs be used to develop guidelines for the health promotion of families with adolescents orphaned by HIV and AIDS.

In view of the findings of the research, the researcher also recommended that:

- All government officials (legislators, traditional leaders and administrators) should respond harmoniously according to the application of relevant policies and legislation when nurses lobby towards provision for health promotion needs for families with adolescents orphaned by HIVIAIDS.

- Through social action the government and nurses should mobilise resources in order to facilitate social change and collaborative networks in health promotion regarding basic needs of families with adolescents orphaned by HIVIAIDS.

- Involvement of nurses, legislators, traditional leaders and administrators in community development to enhance health promotion behaviours in families with orphaned adolescents.

- Organisational stakeholders (managers and traditional leaders) should be consulted regarding application of policies and allocation of resources with emphasis of Maslow's Hirarchy of Human Needs.

- Nurses should influence organisational managers and traditional leaders to train the community to utilise available support programmes responsibly .

- Nurses should develop and utilise networks consisting of accessible and relevant services to the benefit of orphaned adolescents.

- Health education should be provided continuously to conscientise families with adolescents about health promotion needs and behaviours.

- Families with adolescents orphaned by HIVI 
AIDS should be screened to identify their health promotion needs that promote their healthy lifestyle.

- Nurses should ensure that families with adolescents orphaned by HIVIAIDS are counselled to cope with loss and limited resources and to meet the needs of these families.

- Nurses should provide culturally sensitive guidance regarding access to resources and support in utilising available resources to satisfy basic, safety and security, love and belonging, self-esteem and self-actualisation needs of these families.

\section{REFERENCES}

ABDOOL-KARIM, SS \& ABDOOL-KARIM, Q 2005: HIVIAIDS in South Africa. Cape Town: Cambridge University Press.

ALLENDER, JA \& SPRADLEY, BW 2005: Community health nursing: Concepts and practice. Philadelphia: Lippincott.

ANDREWS, MM \& BOYLE, JS 2003: Transcultural concepts in nursing care. Philadelphia: Lippincott.

BABBIE, E \& MOUTON J 2007: The practice of social research. Cape Town: Oxford University Press.

BURNS, N \& GROVE, SK 2001: The practice of nursing research: Conduct, critique \& utilization; $3^{\text {rd }}$ edition. Philadelphia: Saunders. BURNS, N \& GROVE, SK 2003: The practice of nursing research: Conduct, critique \& utilization; $3^{\text {rd }}$ edition. Philadelphia: Saunders. CARPENITO-MOYET, LJ 2003: Maslow's hierarchy needs-revised. Nursing Forum, 38(2):3-4.

CRESWELL, JW 2003: Research design: Qualitative and quantitative Approaches. California: Thousand Oaks.

CRIME BUSTER OF SOUTH AFRICA 2004: South Africa the Rainbow Nation. Available at http://www.CrimeBustersZa.com (Accessed: 25 May 2005).

DE HAAN, M; DENNILL, K \& VASUTHEVAN, S 2005: The health of Southern Africa. Johannesburg: Juta.

DENNIL, K; KING, L \& SWANEPOEL, T 2002: Aspects of primary health care: Community health care in South Africa. Cape Town: Oxford University Press.

DEPARTMENT OF HEALTH 2000: HIVIAIDS/STD strategic plan for South Africa. 2000-2005. Pretoria: Department of Health.

DEPARTMENT OF HEALTH 2001a: National guideline on homebased care and community-based care. Pretoria: Government Printers.

DEPARTMENT OF HEALTH 2001b: Policy guideline for youth and adolescent health. Pretoria: Government Printers.

DEPARTMENT OF PUBLIC SERVICEAND ADMINISTRATION 1997:

Batho Pele principles White Paper: Putting people first. Pretoria:
Government Printers.

EDELMAN, CL \& MANDLE, E 2002: Health promotion: Throughout the lifespan; $5^{\text {th }}$ edition. St. Louis: Mosby.

ELFITURI, AA; ELMAHAISHI, MS \& MACDONALD, TH 1999: The role of health education programmes within the Libyan community. 5(2):263-276. Available at http://www.emro.who.int/Publications/EMHJ/0502/08.htm (Accessed: 30 August 2005).

FRIEDMAN, MM; BOWDEN, VR \& JONE, EG 2003: Family nursing: Research, theory and practice. Connecticut: Prentice Hall.

KALIDEEN, N 2003: AIDS orphans need urgent help. Available at http://www.journ-aids.org/reports/27112003a.htm (Accessed: 12 April 2005).

KESSLER, R 2002: Passages: Fostering community heart and spirit in adolescent education. Available at: http://www.newhorisons.org (Accessed: 31 May 2005).

KINGDOM, G \& KNIGHT, J 2005: Unemployment in South Africa: A microeconomic approach. Available at http://www.csae.ox.ac.uk/ resprogs/usam/default.html (Accessed: 25 January 2007).

LEHANA, TV \& VAN RHYN, L 2003: A phenomenological investigation of experiences of pregnancy by unmarried adolescents in Maseru. Health SA Gesondheid, 8(1):26-38.

LINCOLN, YS \& GUBA, EG 1985: Naturalistic inquiry. London: Sage. MARKER, S 2003: Unmet human needs. University of Colorado: Intractable Conflict Knowledge Base Project.

MBEKI, T 2004: State of Nation Address. Pretoria: Government Communication.

MENGEL, N 2003: A social work assessment of the emotional needs of HIVIAIDS orphans. Pretoria: University of Pretoria (Unpublished M Cur dissertation).

MONTH OF YOUNG ADOLESCENTS 2005: Expressions from the middle. http://www.nmsa.org/moya/-2004/related-youngadol.htm (Accessed: 31 May 2005).

MURRAY, RB \& ZENTNER, JP 2001: Health promotion strategies through the lifespan. New Jersey: Apprentice Hall.

PEARSALL, J 2002: Concise Oxford English Dictionary. New York: Oxford University Press.

POLIT, DF; BECK, CT \& HUNGLER, BP 2001: Nursing research: Principles and methods; $5^{\text {th }}$ edition. Philadelphia: Lippincott.

QUIN, FM 2000: Principles and practice of nurse education. United Kingdom: Ashford Colour Press.

RAMSDEN, N 2002: Community help for children living in an HIV+ world: Bringing hope to orphaned children. Durban: The Press Gang.

REPUBLIC OF SOUTH AFRICA 1996: Government Gazette 378(17678). Cape Town: Creda Press.

ROSSOUW, D 2003: Intellectual tool: Skills for human sciences. Pretoria: Van Schaik.

RICHTER, S \& PEU, MD 2004: The educational and supportive needs of informal caregivers working at Refentse Clinic, 
Hammanskraal. Curationis, 27(1):31-40.

SIAENS, C; SUBBARAO, K \& WODON, Q 2003: Are orphans especially vulnerable? Evidence from Rwanda. Rwanda: World Bank. SOUTH AFRICA 1996: The South African Constitution. Pretoria: Government Printers.

SOUTH AFRICAN GOVERNMENT INFORMATION 2003: AddresS by President of South Africa, Thabo Mbeki, at the celebrations of the 9th million South African household to receive water.

SPECTOR, RE 2004: Cultural diversity in health and illness. Connecticut: Appleton \& Lange.

UNAIDS 2006: Report on the global AIDS epidemic. Geneva: World Health Organization.

VAN RENSBURG, HCJ 2004: Health and health care in South Africa. Pretoria: Van Schaik. 